\section{ELK \\ Asia Pacific Journals}

ELK Asia Pacific Journals - Special Issue

ISBN: 978-81-930411-4-7

\title{
PREPARATION AND MECHANICAL PROPERTIES OF SINTERED ZRB 2 -GRAPHITE COMPOSITES BY SPARK PLASMA SINTERING (SPS) METHOD
}

\begin{tabular}{|l|l|l|}
\hline Nitesh Kumar & Binay Kumar* & Lokesh.C. Pathak \\
Production Engineering & Production Engineering & CSE- Division \\
BIT Mesra & BIT Mesra & CSIR-NML \\
Ranchi, India & Ranchi, India & Jamshedpur, India \\
nk89rnc@gmail.com & binaykumar77@gmail.com & lokesh@nmlindia.org \\
\hline
\end{tabular}

\begin{abstract}
Zirconium diboride-Graphite $\quad\left(\mathrm{ZrB}_{2}-\mathrm{C}\right)$ composite is fabricated by spark plasma sintering (SPS) process. The $\mathrm{ZrB}_{2}$ powder is prepared by single step carbothermal process. The synthesized powder is mixed with Graphite powder (with varying composition of $5 \mathrm{wt} \%$ and $10 \mathrm{wt} \%$ of C) is compacted and subsequently densified using SPS. The formation of phases in the sintered composites along with its density, porosity, Vickers hardness, and micro structural characteristics are investigated. The study revealed that the $\mathrm{ZrB}_{2}-5 \mathrm{wt} \% \mathrm{C}$ composite showed dense microstructure and better mechanical performance.
\end{abstract}

Keywords: SPS, UHTC, ZrB2-Graphite Composite, Densification

\section{INTRODUCTION}

The Ultra-High Temperature Ceramics (UHTCs) has shown enormous potential for applications in various fields of engineering particularly in the aviation or space industries due to its unique high temperature sustainability and mechanical properties. Amongst various UHTCs, $\mathrm{ZrB}_{2}$ has been studied extensively for the last two decades. It has exceptional combination of high melting point $\left(>3000^{\circ} \mathrm{C}\right)$, high thermal and electrical conductivity, moderate density $\left(6.09 \mathrm{~g} / \mathrm{cm}^{3}\right)$, and excellent chemical and physical stability in various atmospheres.

In manufacturing sector, the utilization of $\mathrm{ZrB}_{2}$ based composites is increased as cutting tool, nozzle,wear part and electrode tool (like $\mathrm{ZrB}_{2}-\mathrm{Cu}$, $\mathrm{ZrB}_{2}-\mathrm{SiC}$ etc.) especially in electrical discharge machining (EDM) to produce complex shapesthat are impossible with the diamond cutting tool $[1,2]$. Some of the $\mathrm{ZrB}_{2}$-based composites failed during operation due to thermal shocks. The addition of graphite in the $\mathrm{ZrB}_{2}$ matrix assumed significance to reduce the thermal shock resistance as well as fracture toughness $\left(4.1 \pm 0.5 \mathrm{MPa}^{1 / 2}\right)$ [7]. The decrease of hardness and flexure toughness may not deter the use of $\mathrm{ZrB}_{2}$-graphite composites particularly for EDM. Preparation of $\mathrm{ZrB}_{2}$ based composites are followed by several routes. In this paper, we have used carbothermally prepared $\mathrm{ZrB}_{2}$ powder and graphite powder in varying percentages (by Weight). The carbothermal process is governed by the following reaction [8].

$$
\mathrm{ZrO}_{2}+\mathrm{B}_{2} \mathrm{O}_{3}+5 \mathrm{C}=\mathrm{ZrB}_{2}+5 \mathrm{CO}(\mathrm{g})
$$

In the carbothermal process, unreacted zirconia is further reduced by the addition of graphite forming $\mathrm{ZrC}$ phase, which is expected to enhance sinterability of these composite powders. It is known that the oxide phase is one of the most inhibitor for densification as it promotes grain growth by vapour phase mass transfer process. The objective of the present study is to fabricate dense $\mathrm{ZrB}_{2}$-Graphite composite with varying graphite content (5 and10wt \%) using spark plasma sintering method.

\section{EXPERIMENTAL DETAILS}

\section{A. Preparation of $\mathrm{ZrB}_{2}$ powder:}

Commercially available Zirconium Dioxide $\left(\mathrm{ZrO}_{2}\right)$, (Purity 97\%, and 3\% impurities, LobaChemie, Pvt. Ltd, India), di-Boron Trioxide $\left(\mathrm{B}_{2} \mathrm{O}_{3}\right)$ (purity $99.94 \%$ and $0.06 \%$ impurities, LobaChemie, Pvt. Ltd, India) and Charcoal activated (Purity 90\%, Merck Specialties, Pvt Ltd. India) were mixed in a jar. For proper mixing of the constituents, the dried powder was milled for 30 minutes using a vibratory cup mill. The mixed powder finally packed inside a graphite crucible and heated at elevated temperatures above $1500^{\circ} \mathrm{C}$ and soaked for $1 \mathrm{hr}$ to yield the powder. High

* Corresponding Author 
ELK

Asia Pacific Journals
ELK Asia Pacific Journals - Special Issue

ISBN: 978-81-930411-4-7 temperature graphite resistance furnace (Thermal technology Inc., USA) was used for the powder preparation and the heating and cooling process was carried out in presence of argon gas.

\section{B. Preparation of $\mathrm{ZrB}_{2}$-Graphite composite by SPS}

For the fabrication of $\mathrm{ZrB}_{2}$-Graphite composites with varying graphite contents, different wt\% of Graphite powders (5 and $10 \mathrm{wt} \%$ ) was added to the synthesized $\mathrm{ZrB}_{2}$.powder. The composite powders were mixed using mortar in methyl-ethyl-ketone (MEK) media. The mixed powder was kept in oven for 30 minute at $80^{\circ} \mathrm{C}$ to remove $\mathrm{MEK}$ by evaporation. The dry powder was kept inside a graphite die (20 $\mathrm{mm}$ in diameter) and then covered with $1 \mathrm{~mm}$ thick graphite sheet and kept inside the furnace (Spark Plasma Sintering, FCT System $\mathrm{GmbH}$, Germany) and heated to $1800^{\circ} \mathrm{C}$ at heating rates $100^{\circ} \mathrm{C} / \mathrm{min}$ and soaked for 10 minutes at $1800^{\circ} \mathrm{C}$. Subsequently, the samples were allowed furnace cooling down to room temperature. All the heating, soaking and cooling were performed in presence of flowing argon gas.

\section{RESULTS AND DISCUSSION:}

\section{A. Characterization of ZrB2-Graphite composites:}

\section{Density and Porosity measurement:}

The densities of these SPs made $\mathrm{ZrB}_{2}$ based composites are evaluated using Archimedes' principle of liquid displacement. Ethylene Glycol $\left(\mathrm{CH}_{2}(\mathrm{OH}) \cdot \mathrm{CH}_{2} \mathrm{OH}\right)$ (Density $\left.1.112 \mathrm{~g} / \mathrm{cm}^{3}\right)$ is used the immersing medium. Density and relative density is obtained for those fabricated composites, where the relative density is calculated by dividing the measured density to theoretical density (Calculated using rule of mixtures). As shown in Table 1, the highest relative density of $99.4 \%$ is achieved in the case of $\mathrm{ZrB}_{2}$ composites with $5 \mathrm{wt} \%$ Graphite.

The porosities of the fabricated $\mathrm{ZrB}_{2}$-Graphite composites is investigated using a Mercury Porosimeter (AMP-60-K-A-1, Porous Micrometry
Inc. USA). The porosity histograms foe SPS made composites are plotted in Fig. 1. It is evident that the composites with $10 \mathrm{wt} \%$ of graphite have more porosities than the composites with $5 \mathrm{wt} \%$ of graphite content in the $\mathrm{ZrB}_{2}$ matrix. The decrease of density with the increase of graphite content is consistent with the porosity data.

Table I. Showing the measured density of SPS made $\mathrm{ZrB}_{2}$-Graphite composites

\begin{tabular}{|c|c|c|c|}
\hline $\begin{array}{c}\text { Compos } \\
\text { ite }\end{array}$ & $\begin{array}{c}\text { TheoreticalDe } \\
\text { nsity }\left(\mathrm{g} / \mathrm{cm}^{3}\right)\end{array}$ & $\begin{array}{c}\text { Actual } \\
\text { Density }(\mathrm{g} / \mathrm{c} \\
\left.\mathrm{m}^{3}\right)\end{array}$ & $\begin{array}{c}\text { Relati } \\
\text { ve } \\
\text { Densit } \\
\mathbf{y}\end{array}$ \\
\hline $\begin{array}{c}\mathrm{ZrB}_{2-} \\
5 \mathrm{wt} \% \mathrm{C}\end{array}$ & 5.91 & 5.87 & 99.4 \\
\hline $\begin{array}{c}\mathrm{ZrB} 2^{-} \\
10 \mathrm{wt} \% \mathrm{C}\end{array}$ & 5.74 & 4.92 & 85.7 \\
\hline
\end{tabular}

\section{Vickers hardness measurement}

The micro-hardness of fabricated $\mathrm{ZrB}_{2}$ based composites (5 and 10wt \%) are measured using Vickers method at $25 \mathrm{gm}$-force. Average Vickers hardness of the $\mathrm{ZrB}_{2}-5 \mathrm{wt} \% \mathrm{C}$ is $22.5 \mathrm{GPa}$ (ranging from 17.3 to $29.8 \mathrm{GPa}$ ) and for $\mathrm{ZrB}_{2}-10 \mathrm{wt} \% \mathrm{C}$ was $15.3 \mathrm{GPa}$ (ranging from 4.3 to $28.3 \mathrm{GPa}$ ). The increase and variation in measured hardness values are due the composite nature of $\mathrm{ZrB}_{2}, \mathrm{ZrC}$, graphite and the presence of porosity in SPS made composites. During micro-hardness measurement, two types (grey \& white) of grains are observed. The low hardness of the grey phase in $10 \mathrm{Wt}$ graphite composites is due to fine structures of these grains and the presence of porosity around these particles, which allowed matrix to deform extensively. Hardness values are presented in Table-II.

Table II. Vickers hardness of $\mathrm{ZrB}_{2-5 w t} \% \mathrm{C}$ and ZrB2-10wt\%C

\begin{tabular}{|c|c|c|}
\hline \multirow{2}{*}{ Composite } & \multicolumn{2}{|c|}{ Vickers hardness GPa } \\
\cline { 2 - 3 } & Grey phase & White phase \\
\hline $\mathrm{ZrB}_{2}-5 \mathrm{wt} \% \mathrm{C}$ & $24.8 \pm 2.67$ & $19.3 \pm 1.34$ \\
\hline
\end{tabular}


ELK

Asia Pacific Journals
ELK Asia Pacific Journals - Special Issue

ISBN: 978-81-930411-4-7
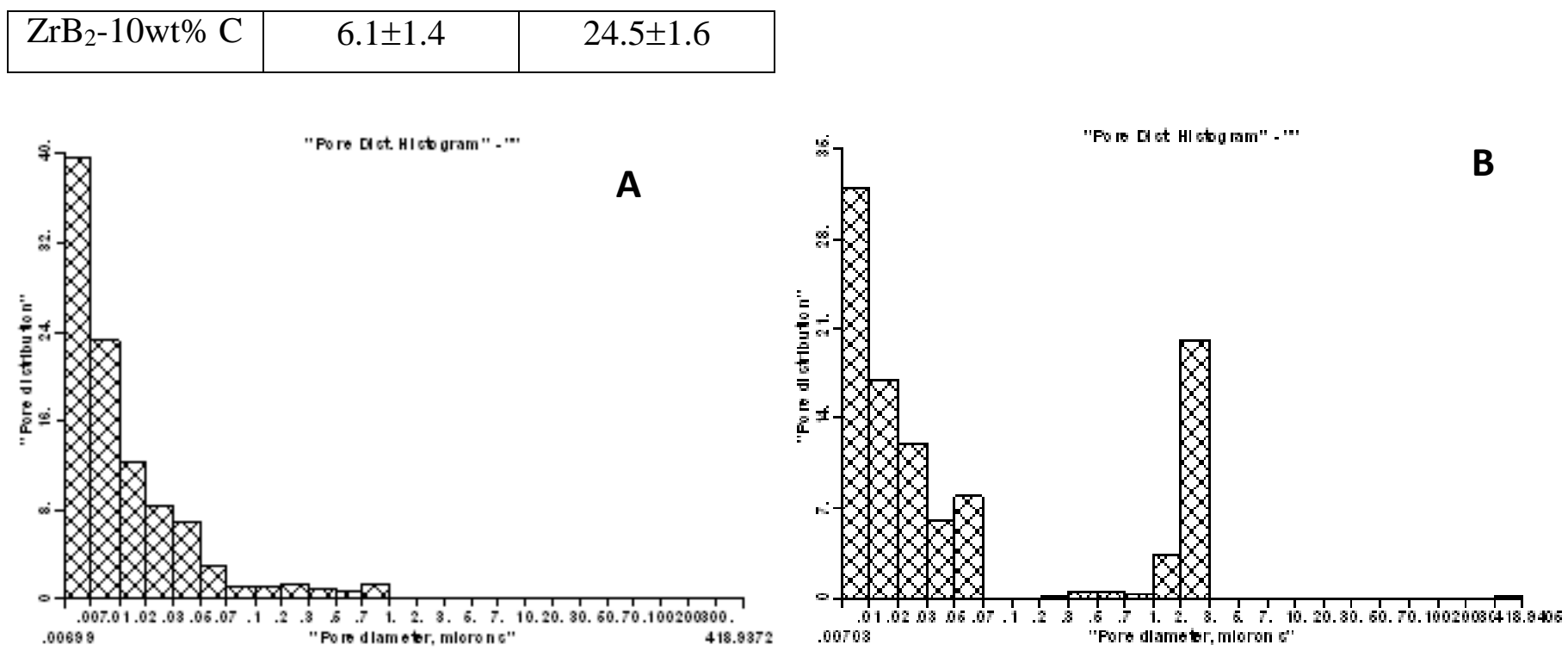

Fig. 1.Porosity of (A) $\mathrm{ZrB}_{2}-5 w \mathrm{w} \% \mathrm{C}$ and (B) $\mathrm{ZrB}_{2}-10 w t \% \mathrm{C}$ composites made by SPS

\section{B. Phase formation and Microstructural study of the SPS made ZrB ${ }_{2-}$ graphite composites:}

X-ray diffraction (XRD) analysis of $\mathrm{ZrB}_{2}$ powder $\mathrm{ZrB}_{2}-5 \mathrm{wt} \% \mathrm{C}$ and $\mathrm{ZrB}_{2}-10 \mathrm{wt} \% \mathrm{C}$ are performed using $\mathrm{Cu}-\mathrm{K} \alpha$ radiation and the respective patterns are shown in Fig. 2. The starting $\mathrm{ZrB}_{2}$ powder has $\mathrm{ZrB}_{2}$ as the major phase along with some amount of unreacted zirconia phase (Fig.1 A). The addition of $5 \mathrm{wt} \% \mathrm{C}$ to $\mathrm{ZrB}_{2}$ leads to the formation of $\mathrm{ZrC}$ as minor phase in the $\mathrm{ZrB}_{2}$ matrix after SPS. The intensities of the $\mathrm{ZrC}$ peaks are increased with the graphite content $\left(\mathrm{ZrB}_{2}-10 \mathrm{wt} \%\right.$ C). The presence of $\mathrm{ZrO}_{2}$ phase as impurities in $\mathrm{ZrB}_{2}$ powder is observed to convert into $\mathrm{ZrC}$ phase by reacting with graphite powder [7]. The formation of $\mathrm{ZrC}$ is governed by the following reaction.

$$
\mathrm{ZrO}_{2}+3 \mathrm{C}=\quad \mathrm{ZrC}+2 \mathrm{CO}(\mathrm{g})
$$

[2]

The $\mathrm{ZrC}$ is also an UHTC material and it is also electrically conducting, which is expected to benefit for the EDM applications. With the addition of graphite, the resistivities of the composites are observed to decrease significantly due to removal of oxide phase.
(C) $7 \mathrm{~B}_{z}-10 w t \% \mathrm{C}$

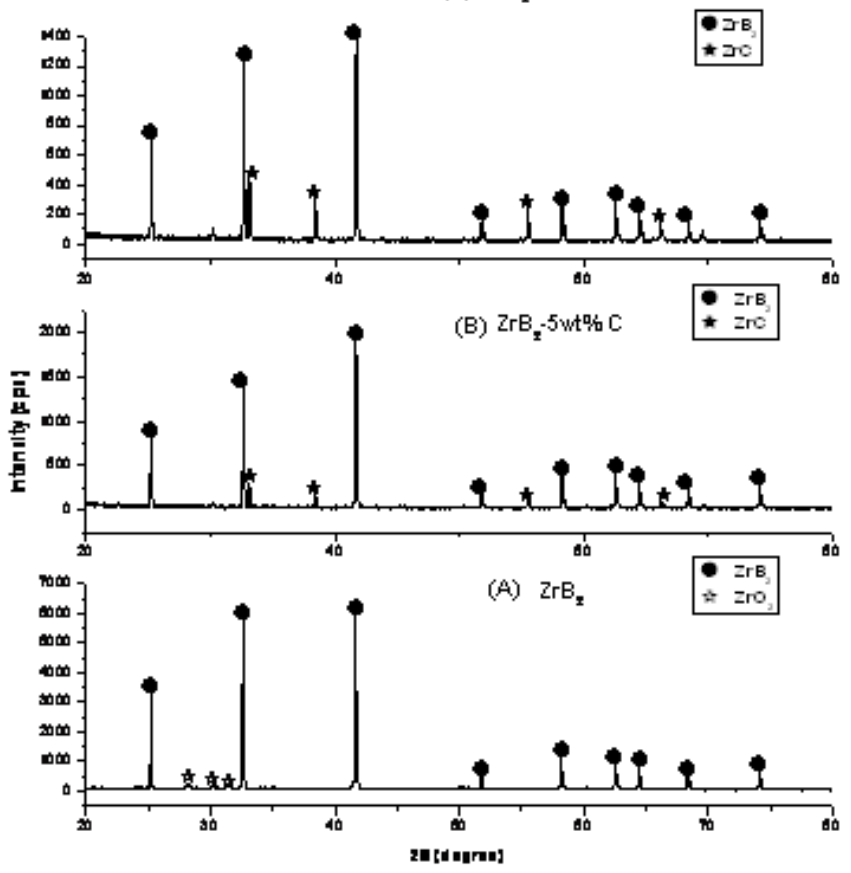

Fig. 2. XRD patterns of (A) $\mathrm{ZrB}_{2}$ powder, (B) $\mathrm{ZrB}_{2}-5 w \mathrm{w} \% \mathrm{C}$ and (C) $\mathrm{ZrB}_{2}-10 w t \% \mathrm{C}$

Surface morphology evaluation by SEM:

The surface morphologies of $\mathrm{ZrB}_{2-}$ (5 and 10 wt\%) Graphite composites are investigated using a scanning electron microscope (SEM) and the respective SEM images are shown in Fig. 3. For the 
ELK

Asia Pacific Journals
ELK Asia Pacific Journals - Special Issue

ISBN: 978-81-930411-4-7

phase analysis, energy dispersive X-ray spectroscopy (EDS) has been used. The EDS analyses indicate that the dark grey phase is $\mathrm{ZrB}_{2}$ having large grain sizes and the light grey grains are of $\mathrm{ZrC}$ compositions, which is having smaller grain sizes (Shown in the image) than the $\mathrm{ZrB}_{2}$ phases. A similar observation was also noted by Mallik et al. [6]. The SEM images also indicate lesser amount of pores in the $\mathrm{ZrB}_{2}-5 \mathrm{wt} \% \mathrm{C}$ composites than the $\mathrm{ZrB}_{2}-10 \mathrm{wt} \% \mathrm{C}$ composites. The excess graphite also acts as grain growth inhibitor for the $\mathrm{ZrB}_{2}$ phase and less grain growth is observed. Similar observations are also reported in literature by S. K. Mishra et al. [9], where it is observed that C addition increase densification till a certain percentages and beyond that percentage it decreases densification. The grain growth has also been reported to decrease with $\mathrm{C}$ addition.

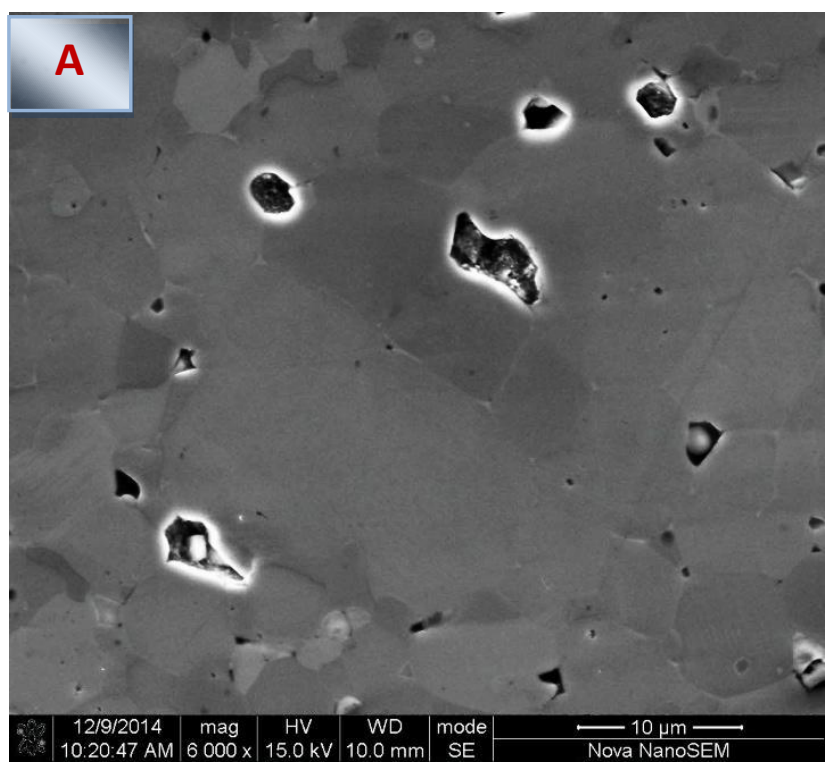

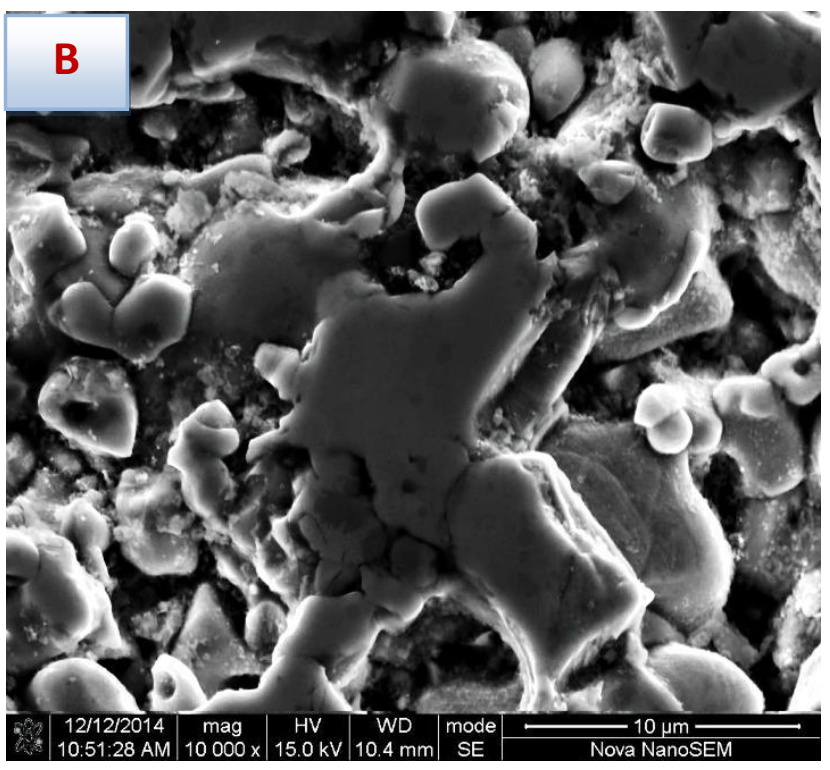

Fig. 3. SEM image of polished surface of (A) $\mathrm{ZrB}_{2}-5 \mathrm{wt} \% \mathrm{C}$ and (B) $\mathrm{ZrB} 2-10 \mathrm{wt} \% \mathrm{C}$

\section{CONCLUSION}

Systematic investigation on the fabrication of $\mathrm{ZrB}_{2}$-graphite composites with varying content of graphite has been carried out using spark plasma sintering method. The oxide impurities present in the carbothermal process is eliminated by adding graphite phases. Dense composites are fabricated when the $\mathrm{C}$ content is $5 \mathrm{wt} \%$ and for $10 \mathrm{wt} \% \mathrm{C}$ content the densification is decreased. The mechanical properties are consistent with the densification and porosity data of the composites. The $\mathrm{ZrC}$ phase found to increase with the $\mathrm{C}$ addition. The conductivity of the composites is also increased with the addition of graphite phase due to removal of zirconia phases in the SPS made composites.

\section{References}

[1] Gaurav Mittal and Sumeshkapil, "Experimental investigation of Material 
ELK

Asia Pacific Journals

Removal rate of $\mathrm{H}-13$ using Powder Metallurgy and conventional electrodes," International Journal of Engineering Science and Research Technology, May 2014, pp. 338343.

[2] A.K.Khanra, B.R.Sarkar, B.Bhattacharya, L.C.Pathak, and M.M.Godkhindi, "Performance of $\mathrm{ZrB}_{2}-\mathrm{Cu}$ Composite as an EDM electrode" Journal of Materials Processing Technology 183 (2007), pp. 122126.

[3] E.Zapata-Solvas, D.D.Jayaseelan, H.T.Lin, P.Brown, and W.E.Lee, "Mechanical Properties of $\mathrm{ZrB}_{2}$ and $\mathrm{HfB}_{2}$ based ultra- high temperature ceramics fabricated by spark plasma sintering" Journal of the European Ceramic Society 33 (2013), pp. 1373-1386.

[4] Ipek Akin, Mikinori Hotta, Filiz Cinar Sahin, Onuralp Yucel, Gultekin Goller, and Takashi Goto, "Microstructure and densification of $\mathrm{ZrB}_{2-} \mathrm{SiC}$ composites prepared by spark plasma sintering" Journal of the European Ceramic Society 29(2009), pp. 2379-2385.

[5] Zhihui Lu, Dongliang Jiang, Jingxian Zhang, and Qingling Lin, "Processing and properties of $\mathrm{ZrB}_{2}-\mathrm{SiC}$ composites obtained by aqueous
ELK Asia Pacific Journals - Special Issue ISBN: 978-81-930411-4-7

tape casting and hot pressing" Ceramics International 37 (2011), pp. 293-301.

[6] ManabMallik, Ansu J.Kailath, K.K.Ray, and R.Mitra, "Electrical and thermophysical properties of $\mathrm{ZrB}_{2}$ and $\mathrm{Hfb}_{2}$ based composites" Journal of the European Ceramic Society 32(2012), pp. 2545-2555.

[7] WangZhi, Wu Zhanjun, and Shi Guodong, "Fabrication, mechanical properties and thermal shock resistance of $\mathrm{ZrB}_{2}$-graphite ceramic" Int. Journal of Refractory Metals and Hard Materials 29 (2011) pp. 351-355.

[8] Songlin Ran, Omer Van der Biest and Jef Vleugels, "ZrB2 Powders Synthesis by Borothermal Reduction" Journal of the American Ceramic Society 93(6), pp. 15861590,(2010).

[9] S K Mishra and LC Pathak "Effect of carbon and titanium carbide on sintering behaviour of zirconium diboride" Journal of Alloys and compounds 465 (1), 547-555 (2008). 